\title{
sciendo
}

\section{Does the shareholder salience influence the corporate social responsibility of entities from energy sector?}

\author{
Bogdan-Ștefan IONESCU \\ Bucharest University of Economic Studies, Bucharest, Romania \\ Bogdan.Ionescu@Cig.Ase.Ro \\ Liliana FELEAGĂ \\ Bucharest University of Economic Studies, Bucharest, Romania \\ Liliana.Feleaga@Cig.Ase.Ro \\ Luminița-Mihaela DUMITRAȘCU \\ Bucharest University of Economic Studies, Bucharest, Romania \\ Mihaela.Dumitrascu@Cig.Ase.Ro
}

\begin{abstract}
The stakeholder salience framework has become, over the past two decades, a tool often used to identify, asses and prioritize stakeholders and has demonstrated considerable theoretical and managerial implications. The objective of this paper is to determine to what extent stakeholder salience influences how different stakeholder categories are represented in the sustainability reports of entities from energy sector. In this respect, an interpretative content-based analysis of the social and environmental information disclosed by entities is used. The sample encompasses six energy entities that are comprised of Dow Jones Sustainability Europe Index (DJSI) constituent's list on September 19, 2016. The results highlight that stakeholders who hold power have a high score of salience, being followed by those who possess legitimacy and then by those who possess urgency. The obtained results suggest the need to continue to focus on the normative theory of the stakeholders. The results also highlight that there is a link between the stakeholder salience, on the one hand, and the number and type of attributes held by each category of stakeholders, on the other hand. Stakeholders who hold power have a high score of salience, being followed by those who possess legitimacy and by those who possess urgency.
\end{abstract}

Keywords: stakeholder salience, energy sector, stakeholders, sustainability reporting, stakeholder claims, power.

\section{Introduction}

Over the past decades, increasing attention has been paid to environmental issues, looking at their impact both from a social and economic point of view, as well as from a political point of view. The environmental components of different products and services are appreciated by the company (Owen, Scherer, 1993). As a result, companies are trying to better respond to the expectations of more and more green consumers and more environmentally-minded investors when deciding on the structure of their portfolios.

From environmental concern, a number of international regulations (ISO 14000, EMAS), European directives (Directive 2013/34/EU, Directive 2014/95/EU) and national legislation have emerged over time. Some of these regulations set obligations for certain companies to publish information about the environmental matters, social and employee related matters and respect for human rights, as well as a description of the policies followed by the enterprises in relation to these 
aspects. In this context, reporting of environmental and social information represents often a challenge for entities to cope with. The requirements on this line come from different sources and cannot be ignored even though they are often complex and it is not easy for managers to decide which issues should respond with priority, given that the entity's resources are limited. As a result, managers have to permanently assess how they respond to different categories of stakeholders, taking into account the attributes they possess. It should be noted, however, that "management may view one stakeholder as inconsequential or minor one day; but find that same group demanding their full attention the next day " (Stephens et al, 2011).

In order to identify stakeholder relevance some researchers (Mitchell et al, 1997) proposed stakeholder salience theory. Stakeholder salience is the degree to which stakeholders are visible, vocal and important to an entity, and is determined by three attributes of stakeholders: power, legitimacy and urgency. The stakeholder salience framework has become, over the past two decades, a tool often used to identify, asses and prioritize stakeholders and has demonstrated considerable theoretical and managerial implications. A review of the literature shows that researchers have not only empirically tested the main proposals of the salience model (Mitchell et al, 1997), but have made efforts to strengthen the theoretical component of the model and to understand the influence of contextual factors on the way managers perceive stakeholder salience.

The objective of this paper is to determine to what extent stakeholder salience influences how different stakeholder categories are represented in the sustainability reports of entities from the energy sector. In this respect an interpretative content-based analysis of the social and environmental information disclosed by entities is used. The results highlight that there is a link between the stakeholder salience, on the one hand, and the number and type of attributes held by each category of stakeholders, on the other hand. Stakeholders who hold power have a high score of salience, being followed by those who possess legitimacy and by those who possess urgency.

We chose the energy sector because it represents a huge market characterized by enormous opportunities for growth. The world needs energy to build a better quality of life and for this reason many investors have shifted towards the energy sector. But providing this energy comes with the responsibility to protect the environment and integrate the corporate social responsibility issues into the company's business model.

Moreover, at global level, the energy sector contributes to the strength of the national economies and also to their growth potential. In this respect, there could be considered that the energy industry has a significant impact on the evolution and functioning of other sectors such as construction, transport, commerce etc. Therefore, given the significant role of the energy sector within the economy of countries, entities which operate in this sector should focus their attention on increasing their value. In this context, the main objective of the companies from the energy sector should be that to concentrate on the generation of value at the level of all categories of stakeholders, including investors, financial institutions, shareholders, employees, customers, members of the management board etc. Going further, considering the large number of stakeholders from the energy sector, compared with other sectors, there is not easy for the entities from the energy industry to meet the expectations of these stakeholders. Therefore, given all these aspects and also the impact of the energy sector on the natural environment, there could be considered that the energy sector needs an integrated reporting based on a corporate social responsibility.

Our article is structured as follows: first, we discuss the background literature on the concept of stakeholders and on the salience framework. Second, we describe our case study, data 
collection, analysis techniques and our findings. In the final section, the conclusions are accompanied by a description of tentative avenues of research.

\section{Literature review}

The organizational performance of an entity can be analyzed and assessed, to a certain extent, on how managers interact with its stakeholders (Wood, 1991 and Clarkson, 1995).

PICBE $\mid 227$

The academic research has reserved a special place for stakeholders, even though this concept becomes vague when it is broken by the American cultural context (Damak-Ayadi et al, 2005). Thus, according to Freeman (1984), the stakeholder is "any group or individual who can affect or is affected by the achievement of the organization's objectives". For Mercier (1999), stakeholders are "all the agents for whom the company's development and good health are of prime concern". Donaldson and Preston (1995) consider that stakeholders are "persons or groups with legitimate interests in procedural and/or substantive aspects of corporate activity". Similarly, Clarkson (1995) speaks of groups or individuals holding "ownership, rights or interests" in an organization. The definition proposed by Bryson (1995) is, however, the most comprehensive one: "a stakeholder is defined as any person, group, or organization that can place a claim on an organization's position, resources or output or is affected by that output."

Starting from the existing definitions, stakeholders have been classified in a variety of ways in their attempt to achieve their prioritization (Nutt, Backoff, 1992). Thus, Caroll (1989) distinguishes between primary stakeholders, who have a direct and contractual relationship with the entity, and secondary stakeholders who, although not having contractual relations with the entity, may be affected by its actions. Kaler (2002) classifies stakeholders in claimants, influencers or a combination of both categories and Pelle Culpin (1998) distinguishes institutional stakeholders, economic stakeholders and ethical stakeholders. Buysse and Verbeke (2003) distinguish between internal primary stakeholders (employees, shareholders and financial institutions) and external primary stakeholders (customers and suppliers), and Lépineux (2003) suggests the classification of stakeholders in the following categories: shareholders; internal stakeholders (employees; labour unions); operational partners (customers; suppliers; banks; and insurance companies); and the social community.

Freeman (1984) believes that managers should identify all stakeholder groups, should determine the importance of each group and the extent to which their requirements are currently met by the entity and, based on the results obtained, should modify the entity's policies in order to take into account requirements remained unsatisfied. Similarly, Pedersen (2011) states that managers need to identify the different groups with which the entity has relationships, take into account their legitimate interests, and develop channels of communication between themselves and the organization, the role of the channels being to allow a dialogue where the needs of the various parties can be genuinely negotiated (Morsing, Schultz, 2006).

In practice, not all entity-stakeholders relationships are considered equally important to managers. This is explained by the complexity of stakeholder relations and the dynamic nature of the entity (Pelle Culpin, 1998). In addition, the managers' interest in stakeholders' requirements is significantly influenced by the financial performance of the entity (Buysse, 2003). That being said, Mitchell et al. (1997) argued that a theory of stakeholder salience "must explain to whom and to what managers actually pay attention". They have identified three attributes of stakeholder salience: the power that a stakeholder group is perceived to have, the legitimacy that it is considered to have and the perceived urgency for its requirements. 
Power is defined as the ability of stakeholders to influence the organization's decisions and the distribution of value (Lépineux, 2003). The use of power as an element of the stakeholder salience is also supported by the neo-institutional theory that coercive pressure strongly influences managers' decisions. Legitimacy is the generalized perception that a group's actions are appropriate in the context of the social system (Morsing, Schultz, 2006). Legitimacy is often connected with power, because normally a manager will not pay attention to a strong actor that he does not considered to be legitimated. The third attribute is the urgency and represents the extent to which a group of stakeholders believe that its claims are time sensitive or critical (Mitchel at al, 1997).

The level of salience varies according to the number of attributes that stakeholders have (Gao and Zhang, 2006). Generally speaking, it is considered that the level is low when the stakeholders have only one attribute, moderated when they have two attributes, respectively high when they have all three attributes. And, obviously, managers pay the greatest attention to the stakeholder groups that have the highest level of salience (Dooley and Lerner, 1994), however, they prioritize their requirements. In this respect, stakeholders are ranked in the following categories: definitive, dominant, dependent, dangerous, dormant, discretionary, demanding, and non-stakeholders (Mitchell et al, 1997). The features of these categories are comprised within Table 1.

Table 1 Stakeholder types according to the salience attributes possessed

\begin{tabular}{|c|c|}
\hline Stakeholder types & Characteristics \\
\hline Dormant & $\begin{array}{l}\text { They have power to impose their desires, but they do not have } \\
\text { legitimacy and urgency. }\end{array}$ \\
\hline Discretionary & $\begin{array}{l}\text { They have legitimacy, but they do not have power in order to } \\
\text { influence the organization, and their requirements are not } \\
\text { perceived as urgency. }\end{array}$ \\
\hline Demanding & $\begin{array}{c}\text { They have urgency requirements, but they do not have power } \\
\text { and legitimacy. }\end{array}$ \\
\hline Dominant & $\begin{array}{l}\text { They have power and legitimacy; they have an impact on } \\
\text { entity. }\end{array}$ \\
\hline Dangerous & $\begin{array}{c}\text { They have power and urgency, but they do not have legitimacy. } \\
\text { They are perceived as dangerous, because they can make } \\
\text { pressure. }\end{array}$ \\
\hline Dependent & They have urgency and legitimacy, but they do not have power. \\
\hline Definitive & They have power, legitimacy and urgency. \\
\hline Non-stakeholders & They do not have power, neither legitimacy, nor urgency. \\
\hline
\end{tabular}

Source: authors, based on previous research ${ }^{2}$ 
Many authors used the conceptual framework created by Mitchell et al (1997). Thus, Agle et al. (1999) demonstrated empirically that there is a positive relationship between the number of attributes held by a stakeholder group and stakeholder salience. Ryan and Schneider (2003) investigated, based on archive information, salience for six categories of institutional investors and recommended that managers be queried about their perception of power, legitimacy and urgency. Magness (2008) studied the reactions of shareholders and managers in the context of two environmental accidents in the mining industry, and pointed out that the stakeholder status is determined by the decision-maker. Parent and Deephouse (2007) highlighted the importance of urgency, stating that, in principle, stakeholders that have the urgency of being the most important attribute are groups of activists, but they concluded that power and legitimacy are more important attributes for the salience stakeholder. Harvey and Schaefer (2001) highlighted that special requirements made by governmental organizations are considered urgent, but government's salience also comes from power and legitimacy. Ullmann (1985) conceptualized the relationship between stakeholders' attributes and the entity's social performance, demonstrating that entities that conduct an active policy of influencing relationships with key stakeholders achieve greater social performance.

Mitchell et al. (1997) suggested that the stakeholders' attributes are variable and that the peculiarities of managers moderate the relationship between these attributes and salience. Rowley (1997) pointed out that the influence of the stakeholders is not only determined by their attributes, but also by how different groups interact and form a network. He demonstrated that entities that are the focus of several stakeholder groups are willing to show higher social performance if those groups coordinate their efforts. Winn and Keller (2001) consider that stakeholder salience is not just about the number of attributes held, but about the degree to which a stakeholder possesses those attributes. Introducing different degrees for the three attributes leads to a more differentiated stakeholder salience image. In addition, this concept is flexible in the sense that, over time, some attributes are lost, others are acquired, and there is the possibility of migrating from one category of stakeholders to another.

\section{Methodological Aspects: Sample Selection, Results And Discussions}

This section contains the research methods used by the author, the main research hypotheses, and the arguments for defining them. The author should explain the qualitative and quantitative methods used and how the research has been designed and performed. The objective of this study is to determine to what extent stakeholder salience influences how different stakeholder categories are represented in the sustainability reports of entities from energy sector.

The sample encompasses the entities from energy sector, the Dow Jones Sustainability Europe Index (DJSI) constituent's list on September 19, 2016. It was verified that these entities have available sustainability reports for 2016 and, in addition, the reports would be drawn up in accordance with Global Reporting Initiative - GRI (2013). The final sample comprises 6 entities from 5 countries and is presented in Table 2. Weber and Marley (2012) demonstrated that nationality is not a differentiation factor for stakeholder salience. Therefore, assuming the inclusion in the sample of entities from just five countries will have a major impact on the results obtained.

Table 1. Company selection 


\begin{tabular}{|l|l|l|}
\hline & Company & Country \\
\hline & Galp Energia SGPS SA & Portugal \\
\hline & NesteOyl & Finland \\
\hline & Repsol SA & Spain \\
\hline & SBM Offshore NV & Netherlands \\
\hline & Technip SA & France \\
\hline & Total SA & France \\
\hline
\end{tabular}

PICBE | 230

Source: authors, based on DJSI constituents' list

Most of the research studies on sustainability have focused on the content analysis of social and environmental information disclosed by entities (Milne and Adler, 1999; Guthrie and Abeysekera, 2006). Content analysis is a technique of understanding and analyzing the content of a text. "The content refers to words, meanings, pictures, symbols, ideas, themes or any messages that can be communicated" (Cho, 2009). The idea behind this technique is to encode qualitative and quantitative information into predefined categories in order to discover patterns in the presentation and reporting of information (Guthrie and Abeysekera, 2006).

Similar to many previous research, our study is limited to documentary evidence and aims to identify "the pattern and content of communication" (Beck et al, 2010). For content analysis of sustainability reports, we considered the methodology developed by Krippendorff (2011), because he identified four units of analysis: sampling units, context units, recording units and enumeration units. Adapted to our study, sampling units are the 2016 sustainability reports. Context units are the narrative sections of the sustainability reports. In order to avoid subjectivity and ambiguity in interpretation, the president's message, forewords, assurance reports, appendices, images and graphs presented in the reports were excluded from the analysis. Recording units are the different categories of stakeholders represented in the sustainability reports. Based on the literature and the GRI guidelines (2013) and after a reading of the reports published by the entities included in the sample, several categories of stakeholders were identified: employees, customers, suppliers, shareholders, community, natural environment and non-governmental organizations. Finally, enumeration units are represented by phrases. The use of phrases as enumeration units helps seeking shared meanings (Rowley, 1997) and permits the comparability with other similar studies (Winn et al, 2001).

The interpretation of texts from the sustainability reports was conducted in relation to the attributes of stakeholder salience (Mitchell et al, 1997), while taking into account the requirements of the GRI (2013) on the relevant social and environmental elements for each category of stakeholders.

Based on the GRI guidelines (2013), the potential requirements for the different stakeholder categories were identified and, after analyzing all the statements in the report that were of interest, the extent to which these requirements were met was assessed as percentage. The results of the 
content analysis in terms of stakeholder requirements are found in Table 3 and these are interpreted in correlation with the expected disclosure level for each stakeholder category.

Table 3. Stakeholder salience for year 2016

\begin{tabular}{|c|c|c|}
\hline Stakeholders group & Stakeholder salience mapping & Stakeholder salience (\%) \\
\hline \multirow{2}{*}{ Employees } & Dominant: 2 entities & $35 \%-43 \%$ \\
\hline & Definitive: 4 entities & $65 \%-77 \%$ \\
\hline \multirow{2}{*}{ Customers } & Dominant: 3 entities & $38 \%-48 \%$ \\
\hline & Definitive: 3 entities & $59 \%-72 \%$ \\
\hline \multirow{2}{*}{ Suppliers } & Dominant: 1 entity & $52 \%$ \\
\hline & Discretionary: 5 entities & $25 \%-35 \%$ \\
\hline \multirow{3}{*}{ Shareholders } & Dominant: 4 entities & $49 \%-54 \%$ \\
\hline & Discretionary: 1 entity & $45 \%$ \\
\hline & Definitive: 1 entity & $68 \%$ \\
\hline Community & Definitive: 6 entities & $39 \%-72 \%$ \\
\hline \multirow{2}{*}{ Natural environment } & Dependent: 5 entities & $40 \%-70 \%$ \\
\hline & Definitive: 1 entity & $60 \%$ \\
\hline $\begin{array}{l}\text { Non-governmental } \\
\text { organizations }\end{array}$ & Discretionary: 6 entities & $25 \%-42 \%$ \\
\hline
\end{tabular}

PICBE | 231

Source: authors, based on research

In most entities, employees are perceived as definitive stakeholders. The interpretative analysis of the information in the sustainability reports highlighted that employees have utilitarian power and legitimacy. Power is closely related to the skills they possess and the legitimacy to the power. It is noted that some entities have high percentages for employee salience $(77 \%)$, while other entities only reach $35 \%$ of the employee-related issues.

For half of the entities, customers are considered definitive stakeholders and for the rest of them dominant stakeholders. It can be noticed that while in the case of some entities the customer group is very well served $(72 \%)$, in others the score is only $38 \%$. Different attitude may be associated with the fact that there are differences from one country to another in terms of competition in the energy field. In other words, we can see that the power of customers influences a high level of attention given to them in the case of some entities and the relatively low level of attention given by other entities. 
As far as suppliers are concerned, their scores are very small, as only a small part of the subjects of interest to them are present in the sustainability reports. For five entities, suppliers were classified as discretionary. This means that they do not have power and urgent claims, but their interest in social and environmental information is legitimate.

Shareholders are classified in different types as there are differences between the entities in the sample as regards ownership of shares. Thus, some entities are mainly owned by institutional investors, by large foreign companies or by the state, and for others the shareholdings is free float. Under these circumstances, in 4 entities, shareholders are dominant stakeholders, in one entity they are definitive stakeholder and in other discretionary stakeholders. However, there is no major difference in the degree to which shareholders' claims are represented in the reports. This is still a proof that power is a determining factor of the salience stakeholder, the absence of urgency and legitimacy, not having too much influence on the salience of entities' shareholders.

The community is the only category of stakeholders characterized by all entities as a definitive stakeholder. Although the score for this group varies from $39 \%$ to $72 \%$, the analysis of the reports highlights that they include consistent sections devoted to activities for local communities, especially educational programs, sporting events, sponsorships and social services. It should be noted, however, that GRI topics on which we have identified as relevant, refer rather to the link between the primary operations of entities and their effects on the well-being of the community.

Natural environment is a dependent stakeholder for 5 entities, being perceived as having urgency and legitimacy but not power. However, scores for the natural environment are high, which means that entities perceive its importance in the current context.

For all six entities in the sample, non-governmental organizations are discretionary stakeholders, because they are considered to be legitimate parties, based on the justifiable nature of their expectations and their willingness to cooperate with the entities. The important aspect of the discretionary stakeholders is that, in the absence of power and urgency, there is no pressure on managers to engage in active relationships with such groups, even if managers choose to do so. It is noted that the score for non-governmental organizations ranges between $25 \%$ and $42 \%$.

The analysis shows that there is a link between the stakeholder's salience, on the one hand, and the type and value of stakeholder attributes, on the other hand. Thus, many of the definitive and dominant stakeholders' requirements are met through corporate sustainability reporting. On average, stakeholders that possess power have the highest scores on salience. They are followed by those who have urgency and legitimacy. In addition, many of the requirements of the definitive and dominant stakeholders are satisfied through corporate sustainability reporting. The results are similar to those obtained by Parent and Deephouse (2007), which demonstrated that the more attributes stakeholders, the salience is higher.

\section{Conclusion and Policy Implications}

In the context in which environmental reporting is a major challenge for accounting practice and research, our study investigates to what extent stakeholder salience influences how different stakeholder categories are represented in the sustainability reports. In order to achieve this, we proceeded to content analysis accompanied by an interpretive analysis for a sample of entities from energy sector, that are the Dow Jones Sustainability Europe Index (DJSI) constituent's list on September 19, 2016. We chose the energy sector because it represents a huge market characterized by enormous opportunities for growth. The world needs energy to build a better quality of life and 
for this reason many investors have shifted towards the energy sector. But providing this energy comes with the responsibility to protect the environment and integrate the CSR issues into the company's business model.

Going further, considering the large number of stakeholders from the energy sector, compared with other sectors, there is not easy for the entities from the energy industry to meet the expectations of these stakeholders. Therefore, given all these aspects and also the impact of the energy sector on the natural environment, there could be considered that the energy sector needs an integrated reporting based on a corporate social responsibility.

First of all, we set up a general list of stakeholders mainly based on the requirements of GRI guidelines. We then analysed the sustainability reports of the entities in the sample to determine the stakeholder attributes in agreement with the conceptual framework of Mitchell et al. (1997). We determined the stakeholders' typology and the level of salience by assessing the degree to which managers prioritize stakeholders' requirements when formulating corporate sustainability reports. In this study, we did not intend to judge corporate sustainability reporting for sample entities, nor to describe how they managed the divergent interests of stakeholders, but only to understand the variables that determine stakeholder salience.

The obtained results allow us to conclude that stakeholder salience theory can be used to determine which stakeholders' requirements are likely to be met through corporate sustainability reporting. Power, legitimacy and urgency appear as valuable hints for stakeholder salience. Thus, power is considered a highly relevant attribute for the managers of the entities in our sample. Then is legitimacy, which is considered a key factor in determining whether an individual or a group is recognized as a stakeholder by the entity, and on the last place is the urgency. Given that all entities in the sample have applied GRI, we believe that the differences in stakeholder salience and sustainability reports are related to the managers' perceptions of the entities rather than to the external reporting guidelines applied.

We consider that the extent to which these results can be generalized is low given the small number of entities included in the sample and the relatively subjective nature of the assessments made in accordance with the chosen research method. There is much scope for further research in this area. Thus, the current study could be extended by resorting to a larger sample and by conducting a multiple financial exercise analysis. Alternative research methods could also be used, such as conducting interviews with different stakeholder categories to test how they perceive organizational activities.

\section{References}

Agle B.R., Mitchell, R. K. and Sonnenfeld, J.A. (1999). Who matters to CEOs? An investigation of stakeholder attributes and salience, corporate performance, and CEO values, Academy of Management Journal, 42, 507-525.

Beck, C.A.; Campbell, D.; Shrives, P.J. (2010). Content analysis in environmental reporting research: Enrichment and rehearsal of the method in a British-German context, British Accounting Review, vol. 42, n. 2: 207-222.

Bryson, J. (1995). Strategic planning for public and non-profit organization (Rev. Ed.), San Francisco: Jossey-Bass Publishers.

Buysse, K., and Verbeke, A. (2003). Proactive environmental strategies: A stakeholder management perspective, Strategic Management Journal, 24, 453-470. 
Caroll A. B. (1989). Business and society: ethics and stakeholder management, O.H.: South Western,Cincinatti.

Cho, C.H. (2009). Legitimation strategies used in response to environmental disaster: A French case study of Total SA“es Erika and AZF incidents, European Accounting Review, vol. 18, n. $1: 33-62$.

Clarkson, M. (1995). A stakeholder framework for analyzing and evaluating corporate social performance, Academy of Management Review, 20, 92-117.

Damak-Ayadi, S. and Pesqueux, Y. (2005). Stakeholder theory in perspective. Corporate Governance: The international Journal of Business in Society, 5-21.

Donaldson. T. and Preston, L. E. (1995). The stakeholder theory of the corporation: Concepts, evidence, and implications, Academy of Management Review, 20, 65-91.

Dooley, R. and Lerner, L. (1994). Pollution, profits and stakeholders: the constraining effect of economic performance on CEO concern with stakeholder expectations, Journal of Business Ethics, 13, 701-711.

Freeman, R.E. (1984). Strategic management: A stakeholder approach, Boston: Pitman. Latest edition Strategic Management: A Stakeholder Approach.

Gao, S.S. and Zhang, J.J. (2006). Stakeholder engagement, social auditing and corporate sustainability, Business Process Management Journal, 12, 722-740.

Guthrie, J. and Abeysekera, I. (2006). Using content analysis as a research method to inquire into social and environmental disclosure, Journal of Human Resource Costing and Accounting, 10, 114-126.

Harvey B.; Schaefer A. (2001). Managing relationships with environmental stakeholders: a study of U.K. water and electricity utilities. Journal of Business Ethics, 30, 243-260.

Kaler, J. (2002). Morality and strategy in stakeholder identification, Journal of Business Ethics, $39,91-99$.

Krippendorff, K. (1980). Content Analysis. An introduction to its methodology, Sage Comm Text Series, Beverly Hills, Ca.

Lépineux F. (2003). Dans quelle mesure une entreprise peut-elle être responsable à l'égard de la cohésion sociale?, Thèse de Doctorat en Sciences de Gestion, C.N.A.M., Paris.

Magness, V. (2008). Who are the stakeholders now? An empirical examination of the Mitchell, Agle, and Wood theory of stakeholder salience. Journal of Business Ethics, 83(2), 177192.

Mercier S. (1999). L'éthique dans les entreprises, Editions La Découverte, collection "Repères", Paris.

Milne, M.J.; Adler, R.W. (1999). Exploring the reliability of social and environmental disclosures content analysis, Accounting Auditing Accountability Journal, vol. 12, n. 2: 237-256.

Mitchell, R. K.,Agle, B. R. and Wood, D. J. (1997). Toward a theory of stakeholder identification and salience: defining the principle of who and what really counts, Academy of Management Review, 22, 853-886.

Morsing, M., Schultz, M. (2006). Corporate social responsibility communication: Stakeholder information, response and involvement strategies. Business Ethics: A European Review, 15 (4), 323-3.

Nutt, P.; Backoff, R. (1992). Strategic management of public and third sector organizations: a handbook for leaders, San Francisco, CA: Jossey-Bas. 
Owen, C.L, Scherer, RF, 1993, Social responsibility and market share, Review of Business, 15(1), 11-17.

Parent, M.M. and Deephouse, D.L. (2007). A case study of stakeholder identification and prioritization by managers, Journal of Business Ethics, 75, 1-23.

Pedersen, E.R.G. (2011) All animals are equal, but...Management perceptions of stakeholder relationships and societal responsibilities in multinational corporations. Business Ethics: A PICBE | 235 European Review, 20 (2), 177-191.

Pelle Culpin C. I. (1998). Du paradoxe de la diffusion d'informations environnementales par les entreprises européennes, Thèse de Doctorat, Université de Paris IX Dauphine.

Ryan, L. V. and Schneider, M. (2003). Institutional investor power and heterogeneity: implications for agency and stakeholder theories, Business \& Society, 42, 398-429.

Rowley, T. J. (1997). Moving beyond dyadic ties: A network theory of stakeholder influences. Academy of Management Review, 22, 887-910.

Stephens, K.K., Malone, P. C. and Bailey, C.M. (2005). Communicating with stakeholders during a crisis: evaluating message strategies, Journal of Business Communication, 42, $390-419$.

Ullmann A. A. (1985). Data in search of a theory, a critical examination of the relationships among social performance, social disclosure, and economic performance of US firms. The Academy of Management Review, 10(3), 540-557.

Winn, M.I. and Keller, L.R. (2001). A modelling methodology for multiobjective multistakeholder decisions: Implications for research, Journal of Management Inquiry, $10,166-182$.

Weber, J. and Marley, K.A. (2012). In search of stakeholder salience: Exploring corporate social and sustainability reports, Business \& Society, 51, 626-649.

Wood, D. (1991). Corporate social performance revisited, The Academy of Management Review, $16,691-717$. 